\begin{tabular}{c} 
ADVANCE RESEARCH JOURNAL OF SOCIAL SCIENCE \\
$\begin{array}{c}\text { ReSEARCH } \\
\text { Volume 11 | Issue 2 | December, 2020 | 40-42 }\end{array}$ \\
$\begin{array}{c}\text { ISSN-0976-5611 } \\
\text { DOI: 10.15740/HAS/ARJSS/11.2/40-42 }\end{array}$ \\
\hline
\end{tabular}

\title{
Parenting stress among parents of normal and disabled children in Haryana state
}

Pinki Rani* and C. K. Singh

Department of Human Development and Family Studies, C.C.S. Haryana Agricultural University, Hisar (Haryana) India (Email : pinki.dx120@gmail.com)

\section{ARTICLE INFO :}

$\begin{array}{lll}\text { Received } & : & 05.07 .2020 \\ \text { Revised } & : & 11.08 .2020 \\ \text { Accepted } & : & 05.09 .2020\end{array}$

\section{KEY WORDS :}

Parenting stress, Disability, Emotional strain, Mental limitation, Behaviour problems

\section{HOW TO CITE THIS ARTICLE :}

Rani, Pinki and Singh, C.K. (2020).

Parenting stress among parents of normal and disabled children in Haryana state. Adv. Res. J. Soc. Sci., 11 (2): 40-42, DOI: 10.15740/HAS/ARJSS/11.2/4042.Copyright@2020:HindAgriHorticultural Society

\begin{abstract}
Parenting stress results when the balance between parents' perception of the demands of parenting outweigh perception of their resources for meeting those demands. The present study will be conducted in Haryana state. Two districts will be selected from Haryana state i.e. Hisar and Sirsa. The location will be selected purposively due to availability of sample. 400 parents (mothers and father) will be selected randomly for sample. 200 parents of normal children and 200 parents of disabled children will be selected from both the location. Two types of variables i.e. independent and dependent were taken. Parenting stress was taken as dependent variable. Parenting Stress Indexshort form (PSI-SF) developed by Abidin in 1995 was used to assess the parenting stress among parents. Result revealed that that highly significant difference were found between parenting stress of mother and father of normal and special children. Mean score shows that mothers of normal children and special children were suffering from more parenting stress than fathers of normal children and special children. Result further reflects that mothers of special children were suffers from higher level of parenting stress.
\end{abstract}

